Editorial

\title{
NOVAS PERSPECTIVAS PARA A ENFERMAGEM
}

Enfim!... a nossa Revista Brasileira de Enfermagem vai à luta depois de várias dificuldades de financiamento entre o CNPq e a FINEP; esta última está financiando parte considerável da REBEn.

Como a enfermagem, no atual momento nacional, a nossa Revista, principal veículo de idéias científicas da comunidade, teve seus percalços. Mesmo com o atraso, iniciamos a entrega dos números de 1987 com a seguinte avaliação: apesar da atual situação econômica e política do País, onde as palavras faladas e escritas não testemunham uma coerência com ações concretas na busca da democratização e da justiça social de que o Brasil tanto necessita, continuamos lutando e estimulando a todos os companheiros enfermeiros e técnicos de enfermagem a cerrarem fileiras conosco na luta pela democratização da sociedade brasileira e das instituições de saúde.

A união da enfermagem em todos os seus níveis internos (enfermeiros, técnicos, auxiliares e os não profissionalizados) se faz necessário para que se possa lutar por uma prática profissional que não seja alienada e nem alienante, com expressão rotineira e repetitiva, mas uma prática crítica e criadora. Para isto se faz mister a união de todos os batalhadores de enfermagem, através, tanto das instituições de saúde, como das entidades de classe nesta reflexão.

Entre 1987 e 1988, iniciamos a discussão junto com a Comissão de Especialistas em Enfermagem do SESu-MEC, da questão do currículo de Graduação que está defasado e não mais nos satisfaz; iniciamos também a discussão da Pós-graduação e as suas inter-relações com a prática e com a formação dos enfermeiros (através do CPEn), tentando buscar as formas de mudança na nossa prática atual.

A questão da formação do grande contingente de pessoas não profissionalizadas que militam na Enfermagem também é motivo de grande atividade por parte das Comissões de Educação e de Serviço de Enfermagem.

A questão da nossa legislação e sua complexidade também é motivo de grande preocupação, visto que é importante o conhecimento dos limites da nossa atual legislação profissional.

Estas são as grandes linhas de trabalho da nossa gestão. Queremos implantar de fato, as novas perspectivas à Enfermagem brasileira, tornando-a atuante, valorizada e com possibilidades efetivas de contribuir na construção das respostas aos grandes desafios nacionais.

Estes desafios são tão grandes quanto o tamanho do Brasil e, por isso é necessário o engajamento de todos. 